\title{
Beyond the state order? Second crop production in the Ferghana Valley, Uzbekistan
}

\author{
Alexander Platonov ${ }^{\mathrm{a}}$, Kai Wegerich ${ }^{\mathrm{b}, *}$, Jusipbek Kazbekova and Firdavs Kabilov \\ anternational Water Management Institute - Central Asia and the Caucasus office. Apt.121, House 6, \\ Osiyo Street, Tashkent 100000, Uzbekistan. Phone: + 998-71-2370445; Fax: + 998-71-2370317 \\ E-mails: A.Platonov@cgiar.org, J.Kazbekov@ cgiar.org, firdavs.kabilov@ gmail.com \\ ${ }^{b}$ International Water Management Institute - East Africa and Nile Basin office. IWMI c/o ILRI, \\ PO Box 5689, Addis Ababa, Ethiopia. Phone: +251 11617 2199; Fax: +251 116172001 \\ E-mail: K.Wegerich@cgiar.org
}

\begin{abstract}
After independence in 1991, Uzbekistan introduced a policy on food security and consequently reduced the irrigated area allocated to cotton and increased the area of winter wheat. Shifting to winter wheat allowed farmers to grow a second crop outside the state-order system. The second crops are the most profitable and therefore farmers tried to maximize the area grown to this second crop. Although the second crops are the most profitable, only few studies have focused on this topic. Evidence is presented which shows that state control of crops has been extended from the main crops, cotton and wheat, to the second crops. Satellite images used for classification of main crops in two provinces of the Ferghana Valley for 2006-2011, highlight that the area utilized for second crops is dependent on the infrastructure that enables access to the water resource, not on the area's position within the irrigation system.
\end{abstract}

Key words: cash crops, Central Asia, Ferghana, loss of water control, second-crop production, state control

\section{Introduction}

Uzbekistan, a former Soviet Socialist Central Asian Republic, has an arid environment and therefore its agriculture depends on irrigation. During the Soviet central management, five year plans, the Uzbek Soviet Socialist Republic (SSR) was required to specialize in the production of cotton. Its production was strictly controlled within a state order system for each particular province, district and state farm. After Uzbekistan gained independence in 1991, the control of Moscow vanished and Uzbekistan slowly introduced land reforms; however, Uzbekistan continued with the state-order system for cotton and added winter wheat to achieve food security, mainly by expanding winter wheat areas and reducing cotton and alfalfa areas. Indeed from being a net importer of wheat in 1991, Uzbekistan became self-sufficient in wheat in 1998. The policy of food security could have had the

* Corresponding author.

(C) Baltzer Science Publishers 
additional benefit of water saving and therefore also the shift could have led to ensure adequate water supply for cotton fields. Nevertheless, the Government of Uzbekistan (GoU) (1993) "recommended" to grow a second crop (maize as fodder crop) after the wheat harvest and even set a limit for the second crop allocated and in 1998 the first decree was issued specifying for each province the amount of hectares to grow maize under second crops to support livestock, poultry and fisheries, which was slowly to increase (1998 to 2000) (GoU, 1998). Because of the overlap with the cotton season the second crop is in direct competition with cotton for resources: water but also labor and fertilizer. While the state-order crop cotton is not profitable for farmers, second crops have been seen from the beginning as cash crops with which individuals could earn additional income (Djanibekov, Rudenko, Lamers, \& Bobojonov, 2010; Pomfret, 2002; Rasanayagam, 2003; Veldwisch \& Spoor, 2008). Hence, through the introduction of winter wheat a competition between state-crops and cash crops were created.

While internationally Integrated Water Resource Management, adaptive management or participation and devolution are promoted on different levels of the water hierarchy (Rahaman \& Varis, 2005) the experience of participatory approaches to water governance and management is mixed and contested (Ingram, 2008; Warner, Wester, \& Bolding, 2008). At the same time, some water experts seem to highlight the success of state-centered management over democratic/participatory management (Mukherji \& Shah, 2005). However, the implication of that claim would be that a central government with state-centered management has full control of policy implementation, water resources as well as the non-government domains. Even back in the 1980s local level water management under state control was described as "populist anarchy" (Seckler, 1982). In the present article state controlled local water management in combination with state-order on crops are evaluated.

The objective of the paper is to highlight the rise of second crop production within Uzbekistan with the example of one irrigation system within the Ferghana Valley as well as to show what appears to be a loss of central control and the appearance of a fragmented approach to tackle the competition between state-order and cash crops.

The paper continues with a section on data and methodology. This is followed by a brief review regarding participatory versus state centered experiences. The next section provides a short introduction to the study area as well as a reflection on the transition period with emphasis on state control within irrigated agriculture. The next section highlights a new approach to tackle the rise of second crops within the Ferghana province, which is followed by a cross check of its implementation. The last section draws conclusions.

\section{Data and Methodology}

Since, official statistical information on cultivated area and water use for crops in Uzbekistan is unreliable, own data sets were created. The following section provides information on how the data was created.

The basis of the data are seasonal Landsat-5 TM and Landsat-7 ETM+ satellite images of 152/032 path/row for the years 2006-2011 years (available at http://glovis.usgs .gov/) (Table 1). 
Table 1

The dates of Landsat images, used for processing.

\begin{tabular}{|c|c|c|c|c|c|}
\hline 2006 & 2007 & 2008 & 2009 & 2010 & 2011 \\
\hline 2006_0325 & 2007_0413 & 2008_0314 & 2009_0512 & 2010_0405 & 2011_0424 \\
\hline 2006_0426 & 2007_0515 & 2008_0517 & 2009_0528 & 2010_0429 & 2011_0502 \\
\hline 2006_0613 & 2007_0616 & 2008_0602 & 2009_0613 & 2010_0702 & 2011_0603 \\
\hline 2006_0731 & 2007_0718 & 2008_0618 & 2009_0621 & 2010_0811 & 2011_0721 \\
\hline 2006_0816 & 2007_0819 & 2008_0704 & 2009_0715 & 2010_0827 & 2011_0822 \\
\hline 2006_0901 & 2007_0904 & 2008_0805 & 2009_0808 & 2010_0904 & 2011_0907 \\
\hline 2006_0917 & 2007_0920 & 2008_0906 & 2009_0824 & 2010_1006 & 2011_1017 \\
\hline 2006_1019 & 2007_1022 & 2008_0922 & 2009_1019 & & \\
\hline
\end{tabular}

The pixel's digital number of infrared (band 4) and red (band 3) spectral bands for each image were converted to spectral radiance using the formula:

$$
\mathrm{L}_{\lambda}=\operatorname{gain} * D N+\text { offset }
$$

Where, $\mathrm{L}_{\lambda}$ is the radiance $\left(\mathrm{W} \mathrm{m}^{-2} \mathrm{sr}^{-1} \mu \mathrm{m}^{-1}\right), D N$ is the digital number of pixels, and gain and offset are the band-specific parameters from the meta-data file.

The values of spectral radiance were converted to the reflectance with the formula:

$$
\rho_{\mathrm{p}}=\frac{\pi * L_{\lambda} * d^{2}}{\operatorname{ESUN}_{\lambda} * \cos \theta_{s}}
$$

where, $\rho_{\mathrm{p}}$ is the at-satellite exo-atmospheric reflectance $(-), \mathrm{L}_{\lambda}$ is the radiance ( $\mathrm{W} \mathrm{m}^{-2} \mathrm{sr}^{-1} \mu \mathrm{m}^{-1}$ ), $\mathrm{d}$ is the earth-to-sun distance in astronomic units at the acquisition date (Markham \& Barker, 1987), $\operatorname{ESUN}_{\lambda}$ is the mean solar exo-atmospheric irradiance $\left(\mathrm{W} \mathrm{m}^{-2}\right.$ $\mathrm{sr}^{-1} \mu \mathrm{m}^{-1}$ ) or solar flux (Neckel \& Labs, 1984), and $\theta_{s}$ is solar zenith angle in degrees (from the meta-data file for each image).

The NDVI (Normalized Difference Vegetation Index) raster layers were calculated for each image, using the formula:

$$
\mathrm{NDVI}=(\mathrm{NIR}-\mathrm{Red}) /(\mathrm{NIR}+\mathrm{Red})
$$

where, NIR and Red are the reflectance in infrared (Band 4) and red (Band 3) spectral bands, respectively.

For each year (2006-2011) from available NDVI, raster layers calculated the maximum NDVI for three seasons: spring (March-May), summer (June-July), and autumn (September-October). The seasonal NDVI layers were used for classification of land use (water, bare soil and grasses) and main crops (winter wheat, double crops, cotton and perennial), using the decision rules (Table 2).

Through the overlaying of WUA's boundaries GIS layers on raster layers of land use the main crop classes were calculated by the amount of pixels for each class inside each WUA.

In addition interviews were conducted with key informants in the Ferghana province water management department. 
Table 2

Decision rules, applied for land use and main crops classification.

\begin{tabular}{lcrr}
\hline Class Name & Spring & \multicolumn{1}{c}{ Summer } & \multicolumn{1}{c}{ Autumn } \\
\hline \multicolumn{1}{c}{ Water } & NDVI $<0$ & NDVI $<0$ & NDVI $<0$ \\
\hline Bare soil & $0 \leq$ NDVI $<0.2$ & $0 \leq$ NDVI $<0.2$ & $0 \leq$ NDVI $<0.2$ \\
Grasses & $0.2 \leq$ NDVI $<0.3$ & $0.2 \leq$ NDVI $<0.3$ & $0.2 \leq$ NDVI $<0.3$ \\
Winter wheat & $0.3 \leq$ NDVI & $0 \leq$ NDVI $<0.3$ & $0 \leq$ NDVI $<0.3$ \\
Double crops & $0.3 \leq$ NDVI & $0 \leq$ NDVI $<0.3$ & $0.3 \leq$ NDVI \\
Cotton & $0 \leq$ NDVI $<0.3$ & $0 \leq$ NDVI $<0.3$ & $0.3 \leq$ NDVI \\
Perennial crops & $0.3 \leq$ NDVI & $0.3 \leq$ NDVI & $0.3 \leq$ NDVI \\
\hline
\end{tabular}

\section{Framework}

While in the past land and irrigated agriculture have been seen as the main source with which states manifest their power (Wittfogel, 1957). In the more recent past, particularly state run irrigation systems have been viewed as failures of state control. Barker and Molle (2004, p. 16) reason that the "public irrigation systems had grown faster than the institutions needed to regulate them. Moreover governments had tried to build irrigation from top down". On the other hand Plusquellec (2002, p.14) points out that "irrigation infrastructure built by the governments consisted only of primary and secondary canals, with a few farm outlets". Some authors even make reference to "populist anarchy" when describing local level water management (Seckler, 1982; Shah, 2009; Wade, 1984). To tame the anarchy, new water governing organizations were promoted on the local (Water User Associations, henceforth WUAs) and basin level (multi stakeholder platforms) with the belief in "self-organization as a way to deal with water issues" (Bressers \& Kuks, 2013, p. 133). Bressers and Kuks (2013) do not distinguish whether the self-organization was self-initiated or introduced from the top.

However, based on findings in Meinzen-Dick (2007), looking at 46 participatory irrigation management programs around the world, as Ingram (2008, p. 3) points out that "participation is only weakly associated with positive results for water management".

The above-mentioned discussion focuses on state control versus decentralized management of water resources. However, for the purposes of the present paper, water governance will be defined as "the political, social, economic and administrative systems that are in place, and which directly or indirectly affect the use, development and management of water resources and the delivery of water service at different levels of society" (Water Governance Facility, 2014). Water governance incorporates the different dimensions of water control technical, organizational, socio-economic and political. Uphoff (1986) first reflected on this, and distinguished between three different but interacting components, the controlling structure, water use and the organization. Uphoff (1991) added different dimensions of the context, technology, economic, socio-cultural and political-legal. This was picked up by Mollinga (2003) who later differentiated between three dimensions of water control: technical, organizational, and societal, economic, and political. Ertsen (2006) highlights that when colonial irrigation systems were constructed these were 
directly designed for certain crop production. Hence, the state controlled often irrigated agriculture not only through technology, organization and legal status but also through the control over the agricultural production. In addition, in some colonial state controlled irrigation systems, the irrigators were controlled through tenant agreements (Bolding, 2004; Ertsen, 2006).

At the same time the state often continues with interventions and directives. Comparing South Asian parliamentary democracies (India, Pakistan, Bangladesh, Nepal, Sri Lanka), with China, they argue that "China has had more success than any of the South Asian countries" (Mukherji \& Shah, 2005, pp. 336, 337). As examples of success they mention the enactment as well as enforcement of water legislation. Highlighting that in China "Every village has a village leader and a village Communist Party leader with strong authority sanctioned by higher echelons of the government and the Communist Party" (Mukherji \& Shah, 2005, p. 337). Hence, they claim (p. 341) "the nature of the political system matters." Overall, Mukherji and Shah (2005) appear to be positive about a strong state that can enact policies on the national level and through its control structures is able to enforce these policies on the local level. While the work of Wittfogel (1957) assumes complete control by the [Oriental] state, one could question whether the state could enforce its national-level policies or whether national-level policies may be changed during implementation. Teisman, van Buuren, Edelenbos, and Warner (2013, p. 2) highlight that "there probably never was a time when a government had all necessary resources at their disposal". However, this observation does not cover the whole spectrum in which a state could achieve compliance within the state. Lustick (2002) identifies four forms of compliance producing mechanisms: coercion, utilitarian, normative and ideological hegemony. According to Lustick, coercion is the least efficient and ideological hegemony the most efficient compliance mechanism. Bressers and Kuks (2013, p. 143) point out that since policy implementation "takes place at another, lower level of government", the underlying assumption is that national policies might not be implemented uniformly and implementation might be hampered from within the bureaucracy. Hence, instead of a state-wide policy there could be a mosaic of different policies within lower administrative units, which could be even in contradiction to other national policies.

\section{Study area}

The Ferghana Valley is located in the middle reach of the Syr Darya River Basin. It is an enormous depression spanning $22,000 \mathrm{~km}^{2}$ between the mountain ranges of the Tien-Shan in the north and the Gissar-Alai in the south. The area of the Ferghana Valley is shared by three countries: Kyrgyzstan, located in the northern, eastern, and southern fringes of the valley, Tajikistan, in the western part and Uzbekistan, in the center of the valley. Three Uzbek provinces are located within the Ferghana Valley: Andijan, Ferghana and Namangan (Figure 1) ${ }^{1}$.

\footnotetext{
${ }^{1}$ The three Uzbek provinces have the following area $\left(\mathrm{km}^{2}\right)$ and population (in million in 2010): Andijan 4,200 and 2.6, Ferghana 6,800 and 3.1 and Namangan 7,900 and 2.3.
} 
The main sources for irrigation are the rivers Naryn (average annual flow $13.8 \mathrm{~km}^{3}$ ) and Karadarya (annual flow $3.9 \mathrm{~km}^{3}$ ), which join in the Ferghana Valley to form the Syr Darya River. Additional sources of water are the small tributaries (total flow: $7.8 \mathrm{~km}^{3}$ ) in the northern and southern part of the Valley.

Crop production in the Ferghana Valley dates back millennia to farming settlements around the oases where irrigation systems were developed (Benjaminovich \& Tersitskiy, 1975). Many main canals were constructed during the time of the Soviet Union to expand the irrigated area within the valley by linking the different oases (sub-basin tributaries of Syr Darya). One of these canals, the South Ferghana Canal (SFC), is $93 \mathrm{~km}$ long and runs through the Andijan and Ferghana Provinces. SFC takes water from the Andijan Reservoir within the Karadarya subbasin and transfers the water from the southeast to the southwest of the valley. The small river Isfayramsai $\left(0.55 \mathrm{~km}^{3}\right)$ contributes to the SFC flow at two points, at Besholish and Margilon in the Ferghana Province (Wegerich, Kazbekov, Mukhamedova, \& Musayev, 2012). In 2010, the SFC covered an area of 140000 ha, which officially included a total of 41 Water User Associations (WUAs) (Figures 2 and 3). Along the SFC WUAs receive water either through gravity, small pumps or large pump stations.

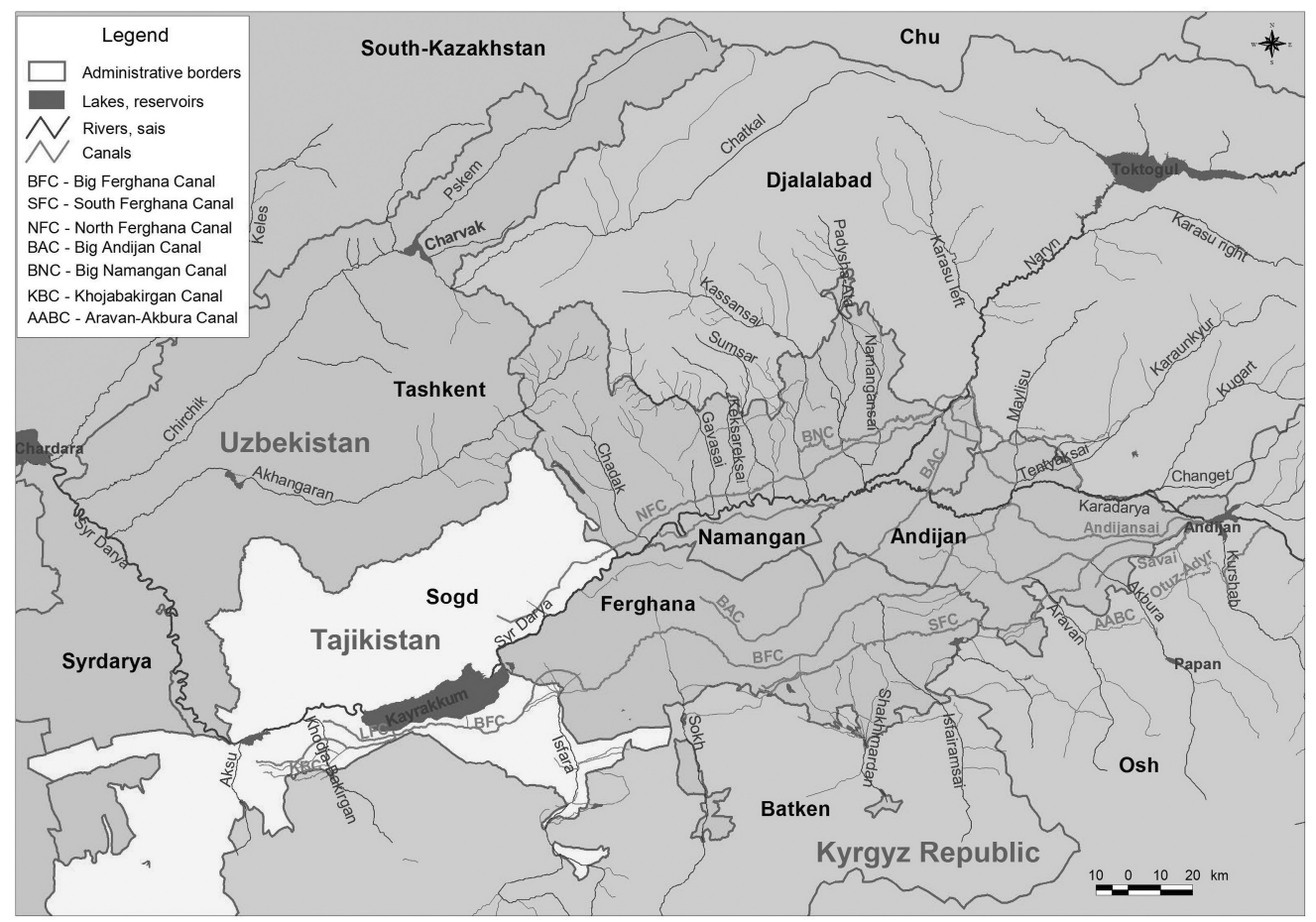

Figure 1. Map of the Ferghana Valley, Uzbekistan. 
After independence in 1991, Uzbekistan introduced a policy of food self-sufficiency and therefore expanded the area under wheat. "The result was an expansion of the winter wheat area from 620000 ha in 1991 to 750000 ha in 1996 and a similar decline in cotton area" (Abdullaev, de Fraiture, Giordano, Yakubov, Rasulov, 2009, p. 59). According to the authors the area under wheat was stable from 1996 to 2006. They argue that "the shift from cotton to wheat area has decreased overall irrigation water requirements" (Abdullaev et al., 2009 , p. 50). The growing seasons of winter wheat and cotton are from October to June and from April to October, respectively. The implication would be that the shift from cotton to wheat would not only reduce the overall water demand but because of the two different cropping seasons it would significantly reduce the water demand during the summer period when demand for water is highest (Spoor \& Krutov, 2003), although there is a competition between irrigation of wheat and cotton in the early cropping season (April-May). Hence, the shift should have led to secure sufficient water for cotton irrigation. This could be particularly important for certain regions in Uzbekistan, particularly the Ferghana Valley, given that water resources are transboundary and the upstream state within the Syr Darya Basin, Kyrgyzstan, controls the main tributary, the Naryn, with the Toktogul Reservoir (Wegerich, 2004a, 2011). Possibly, because of this high level of transboundary water dependence

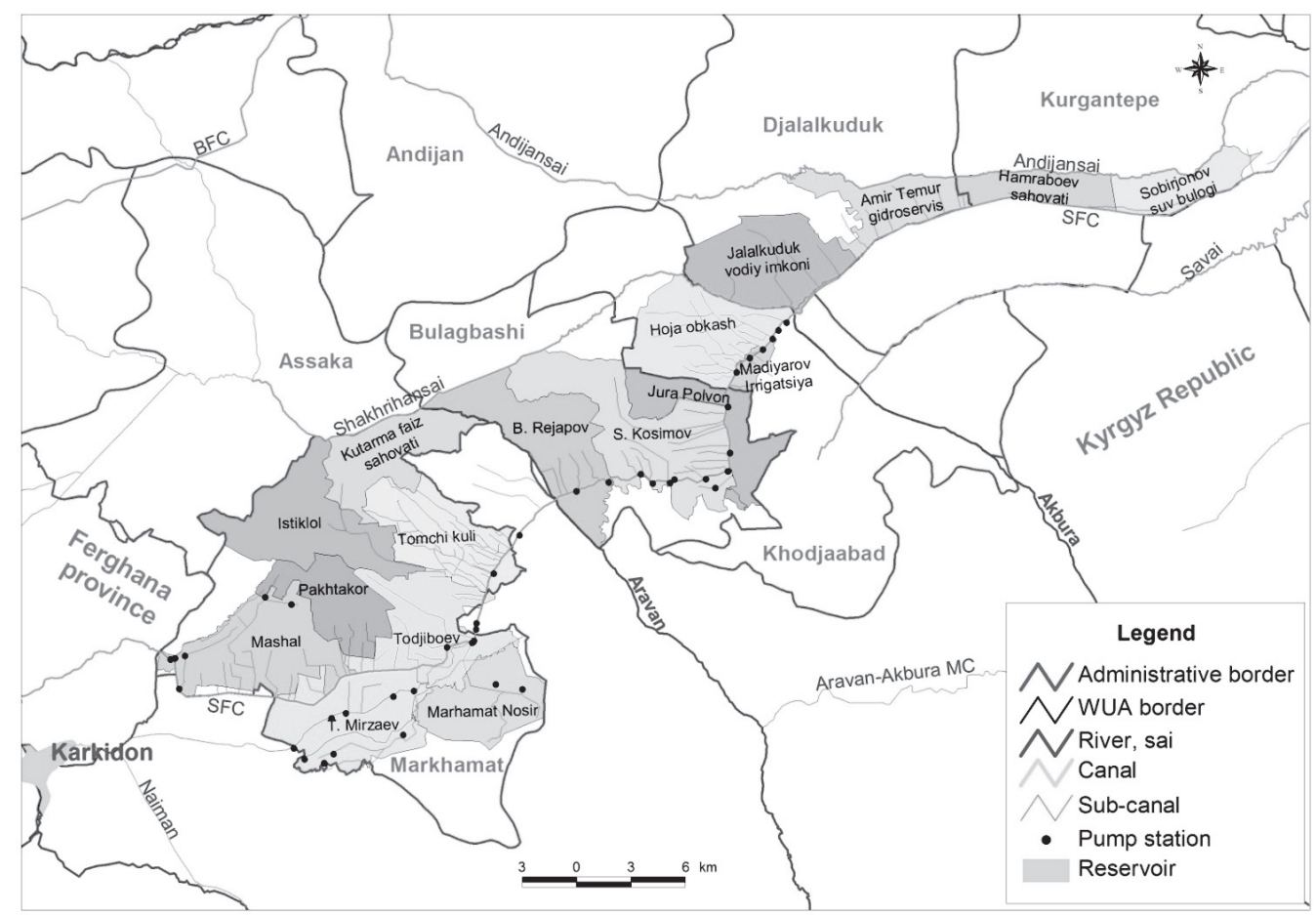

Figure 2. Water User Associations along the South Ferghana Canal in Andijan Province, Uzbekistan. 


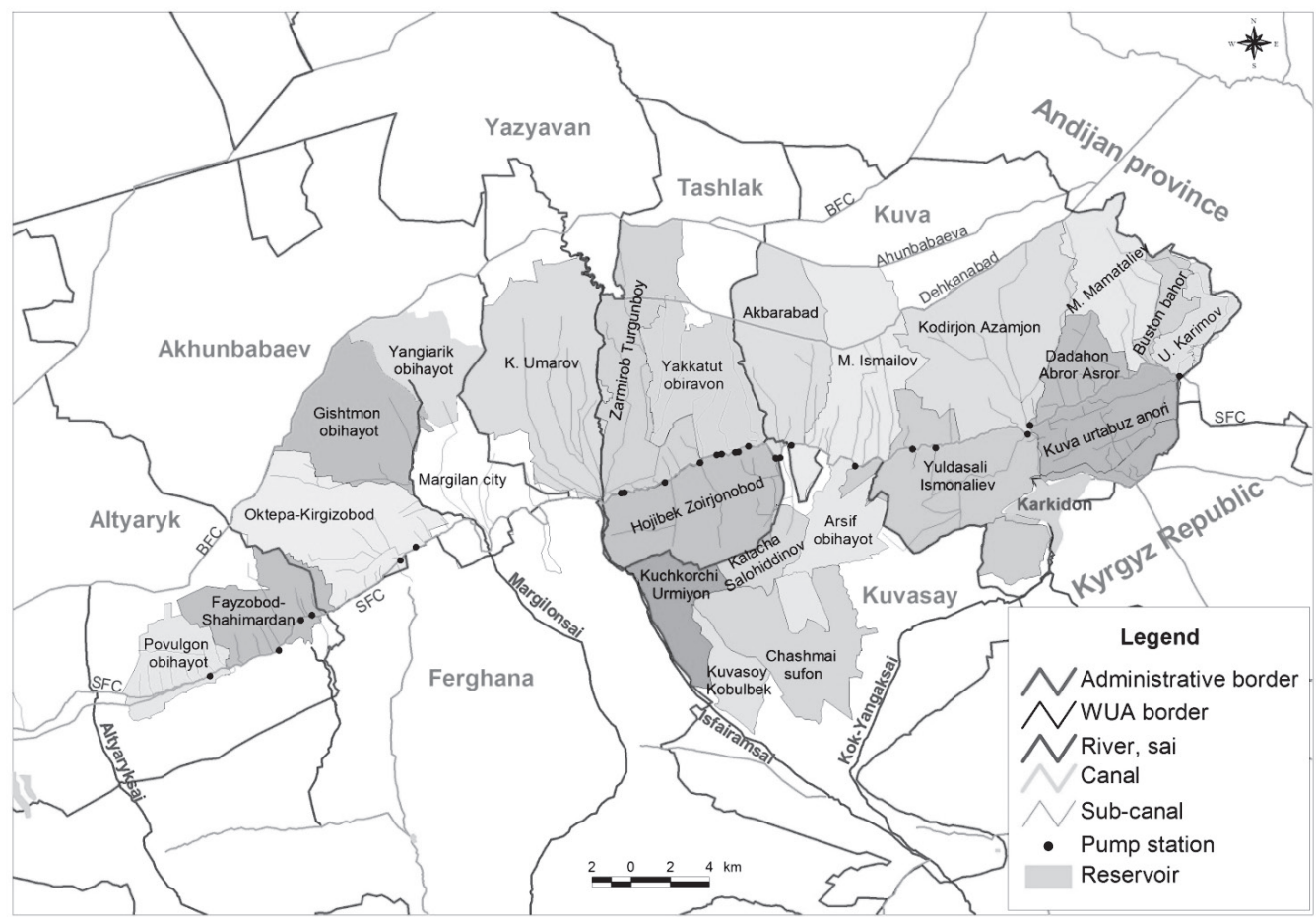

Figure 3. Water User Associations along the South Ferghana Canal in Ferghana Province, Uzbekistan.

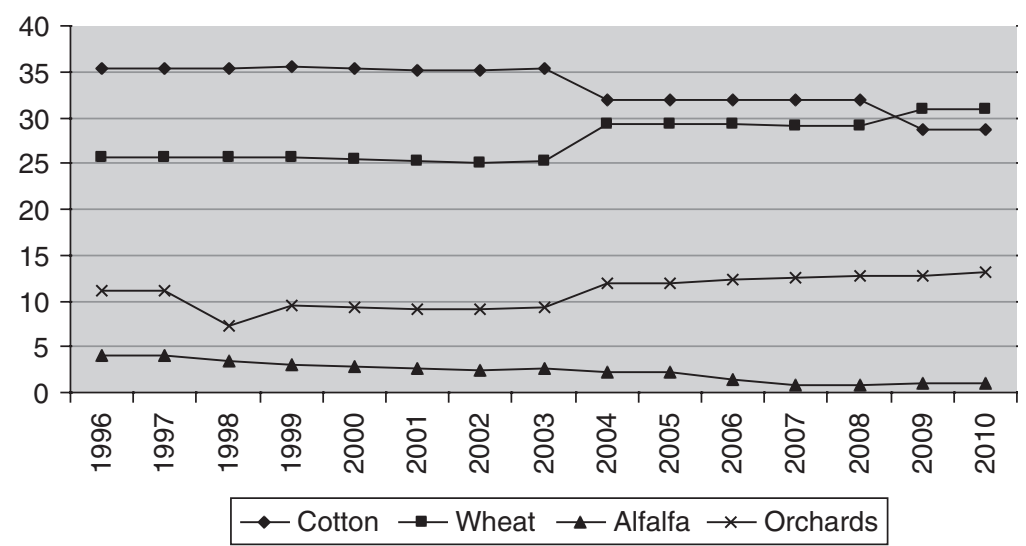

Figure 4. Main crops area (\%) in the Ferghana Province.

within the Ferghana Valley the growing of winter wheat continued to increase up to 2010 and, in the same period, the area allocated to cotton has decreased as exemplified by Ferghana Province (Figure 4$)^{2}$.

${ }^{2}$ Although the Ferghana Valley's state crops, cotton and wheat are dominant, the Ferghana Valley is also a major producer of fruits and vegetables. Because of local demand, many other crops (maize for grain, mung bean, millet and tobacco) are grown on a smaller scale as well. In addition to annual crops, the area is covered with orchards, vineyards, and walnut and mulberry tree plantations. 


\section{Transition from state control}

International publications around the end of the 1990s and beginning of the 2000s have indicated that after independence Uzbekistan continued with keeping strict control of the rural population through its cotton sector through the continuation of state and collective farms as well as the continuation of the state order system of cotton (Jones, 2000; Spoor 1998; Weinthal, 2001) or that local rural communities (mahallas) were and still are strictly controlled by the government through top-down appointments of officers (Massicard \& Trevisani, 2003). Nevertheless, already during the time of continued state control of agricultural production, nepotism between state representatives and private interest was observed (Rasanayagam, 2003; Wegerich, 2004b, 2006). In addition, during the transition period (after independence from the Soviet Union), the water sector started to lose control over equitable water allocations (Wegerich, 2004c, 2005), resulting in more head and tail-end problems within the irrigation systems as well as within the basin (Dukhovny, 2002; Wegerich, 2007).

Although, the GoU (1998) issued a decree on second crops (irrigated crops after the winter wheat harvest) in 1998 for the years 1998 to 2000, the year 2000 and 2001 were exceptionally dry years. Since there is competition between the state-order crop cotton and the second crop, it might be that during the drought year 2000 the plan for second crop was discarded because of the competition over water between cotton and second crops.

With land reforms, the dismantling of state and collective farms and the introduction of private farms, kicking off in the late 1990s and gaining momentum in the early 2000s the power of the state was further eroded, because only a small number of persons could get access to land ${ }^{3}$ (Wegerich, 2010), 'optimization' further reduced the number of farms (Mukhamedova \& Wegerich, 2014). Although the main part of the rural population was excluded from owning land ${ }^{4}$, they still generate some of their income through agricultural activities. According to findings of Yakubov (2013) the rural non-farmer population has a diverse livelihood approach, gaining about 13\% (in SFC) and 23\% (in Big Andijan Canal) of their income directly from on-farm work (other sources are kitchen garden - 28 and $22 \%$, livestock and poultry 24 and 18\%, non-farm activities 27 and 30\%, social allowances 8 and $9 \%$, respectively). Hence, overall the control of the rural population through agricultural production started to fade.

The loyalty of the remaining farmers to the state was reduced further, having shifted from being state employees with fixed income to a farmer under the state-order system for cotton, which offers little financial benefits (Trevisani, 2007). In this context it is helpful to refer to Veldwisch's (2007) discussion of Khorezm province, also in Uzbekistan but located in the lower Amu Darya basin. The author (2007, p. 107) sees second crops as a reward given to farmers if they produce cotton, arguing that "the delivery of outputs in

\footnotetext{
${ }^{3}$ Uzbek land reforms aimed to ensure economies of scale and continued high cotton production, consequently only a few, larger farms were created on the former collective farm lands.

${ }^{4}$ For example, the total population of Ferghana Province was 3.1 million and the number of private farms was 11,126 in 2010 (Mukhamedova \& Wegerich, 2014).
} 
the state-ordered form of production is an important requirement for being allowed to develop the commercial production [second crop]". However, according to him this reward is informal: "In May and June farmers were waiting to get the permission to grow rice. Eventually, these permissions never came in writing, but rather as vague indications that it is would be alright" (Veldwisch, 2007, p. 101). Hence, according to Veldwisch (2007) second crops are only grown with permission from the higher level, reasoning that "it is also in their [hokim/governor's] interest to allow for substantial areas of rice to be planted. This is because they have a role as benefactor and patron in their communities and at the same time it creates opportunities to gain some personal benefit" Veldwisch (2007: p. 15). However, Veldwisch leaves open what kind of personal benefits could be gained.

Conrad (2006) presents data on second crops after winter wheat for Khorezm Province for 2005. According to him, the winter-wheat area in Khorezm is about $20 \%$ of the total irrigated area. Conrad (2006, p. A34-A37) shows that about $90 \%$ of the area allocated to winter wheat after the harvest is utilized for second crops, with a large proportion of the second crop being rice.

Neither Conrad nor Veldwisch make reference to second crops as being part of the state-order, similarly regarding access to water, it appears that none of the researchers detected a set water limit for second crops. According to Veldwisch $(2007$, p. 101) the limiting factor for second crop is water: "it has become clear the total area that can be permitted to grow rice by the governmental organization is connected to water availability". However, Conrad (2006) observes an equally large area of land utilization for second crops in all WUAs independent of their location within the analyzed irrigation system in Khorezm for 2004 and 2005. Given that rice is the dominant second crop in Khorezm there would have been large competition between the commercial crop rice and the state-order crop cotton especially since there was not a water limit for second crops. However, Conrad (2006, p. 187) highlights that $37 \%$ more water was utilized in Khorezm compared with the official statics of ICWC. The utilization of additional water in Khorezm would have had a negative impact on the downstream user the autonomous Republic of Karakalpakstan within Uzbekistan (Dukhovny, 2002; Wegerich, 2007).

Table 3

Proportion of second crop after winter wheat in Khorezm (2005).

\begin{tabular}{lcrrrrr}
\hline Irrigation systems & Klichnyasbay & Daryalik & Tash-Saka & \multicolumn{1}{c}{ R-8 } & Palvan-Gazavat & Palvan \\
\hline total area (ha) & 43,978 & 21,359 & 140,020 & 31,195 & 20,000 & 47,000 \\
wheat area (ha) & 5,915 & 3,336 & 24,279 & 5,699 & 4,088 & 7,727 \\
wheat-rice (\%) & 44 & 25 & 40 & 41 & 44 & 32 \\
wheat-other (\%) & 42 & 65 & 47 & 51 & 50 & 58 \\
wheat-without (\%) & 14 & 10 & 13 & 8 & 6 & 10 \\
\hline
\end{tabular}

Source: Adapted from Conrad (2006: A34-A37). 


\section{Second Crops in the Ferghana Province}

There is a clear trend in the Ferghana Province in expanding the area under winter wheat and orchards and decreasing the area for cotton and alfalfa (Figure 3). A key informant confirmed that the growing of second crops began right after the state order for winter wheat was introduced, hence already during the time, when collective farms were still not privatized (interview with key informant from Unified Dispatch Center for Main Canal Management Organizations of Ferghana Valley, 05/06/2013).

While the studies conducted in Khorezm have shown that there is some informal link between the local government and farmers growing second crops, this link appears to be formalized in the Ferghana Province. After the water scarce year of 2008, a provincial decree mechanism was introduced in Ferghana Province for 2009 (interview with key informant, 05/06/2013). It was not possible to confirm the existence of a provincial decree for Andijan province. On the other hand, Dukhovny et al. (2012) show that setting water limits for second crops already started before the mentioned provincial decree mechanism. Water limits for second crops were set for Andijan as well as for Ferghana province (Figures 5 and 6).

It appears that the government tries to control not only the area under second crops but also the second crop itself. Evidence was found in the provincial department of the Ferghana Province in the form of a resolution which not only allows the growing of second crops, but also obliges the agricultural and water departments to facilitate the production of second crops formally and sets quotas as a percentage of the irrigated lands after the wheat harvest. The resolution links the suggested lands for second crops to water availability of the given year (cropping season). The resolution appears to suggest that secondcrop farming became state-organized contract farming, similar to the production of cotton and wheat. Hence, it appears that the state within the Ferghana Province, rather than moving more into privatization of agriculture, is steadily expanding the grip on the farmers. The reason for this resolution is the necessity to systematically organize water and land resources and to match agricultural production with the food demands of the population (interview with key informant, 05/06/2013). ${ }^{5}$ The resolution states the following (translated from Uzbek) (Box 1):

\section{Box 1: Extracts from Ferghana Province Resolution on second crops (2011)}

1. Approval of the order on sowing of second crops after harvesting of cereal crops in 2011.

2. To commit the provincial administration of agriculture and water resources, SyrdaryaSokh Basin Irrigation System Authority, the hokims of Quvasoy and Ferghana cities and all districts:

- Do not allow the second crops area to exceed the sowing plan.

- To ensure during the allocation of second crops that vegetable, cucurbits, potato and other crops are sown in areas for fulfilling the food requirements of the population.

(Continues)

\footnotetext{
${ }^{5}$ Recently, at local food markets areas of Uzbekistan food products were offered at less than market prices. With this new policy Uzbekistan is trying to secure the access to food products of the urban lower income classes.
} 
(Continued)

- To organize the allocation of area for second crops, according to the current amount of livestock in stock-breeding farms.

- To make contracts with agricultural farms on second crops in addition to the contract on long-term land leasing.

- To assure that the planting of second crops will not cause water shortages for cotton crops.

3. To commit the agricultural and water management department of the province, the hokims of cities and all other districts:

- To plant the fast ripening varieties of corn for getting a highly productive harvest and to create the corn feed base.

- To make contracts with farmer associations for providing maize according to the plan of corn planting

- To prove farmer associations with advance financing, seeds, minerals and fuels in time to grow maize according to contracts,

4. The farmer associations should fulfill the agro-technical work (cultivation, seeding, irrigation, pest management, and harvest) in time and according to contracts.

5. Seeds, fuels and minerals should be bought from the authorized stock exchange only.

6. Farmer associations are solely responsible for the collecting of the autumn tillage after the harvesting of second crops.

7. The responsible person for this decree performance is the first head of the provincial administration.

Source: Decree (2011).

The resolution entails in detail the list of second crops with determined number of hectares for each district within Ferghana Province (Table 2). It assumes that each district department drafts similar plans for allocating second crops to individual farmers growing winter wheat. Since these second crops, unlike cotton, can be traded on the local markets it is to assume that although the resolution suggests state control, it creates incentives for deviance in terms of allocating specific crops to individual farmers, because some crops are more profitable than others. ${ }^{6}$

Table 4.

Plan on sown area of second crops in the Ferghana Province (2011).

\begin{tabular}{|c|c|c|c|c|c|c|c|}
\hline \multirow[b]{2}{*}{ District name } & \multirow[b]{2}{*}{$\begin{array}{l}\text { Second crops } \\
\text { area, ha }\end{array}$} & \multicolumn{6}{|c|}{ including } \\
\hline & & Vegetables & Potato & Melon & $\begin{array}{l}\text { Maize } \\
\text { for grain }\end{array}$ & $\begin{array}{l}\text { Maize } \\
\text { for silage }\end{array}$ & Rice \\
\hline Quvasoy c. & 1,589 & 256 & 250 & 2 & 468 & 613 & \\
\hline Ferghana c. & 764 & 353 & 81 & 2 & 108 & 220 & \\
\hline Besharyk & 3,525 & 730 & 237 & 9 & 1,053 & 1,446 & 50 \\
\hline
\end{tabular}

\footnotetext{
${ }^{6}$ The resolution makes no reference to the details of the contractual relations between the state organization and farmers. One could assume that the situation is similar in Khorezm and Ferghana Province and that farmers have to provide a certain percentage of their harvest to the state.
} 
Table 4.

(Continued)

\begin{tabular}{lrrrrrrr}
\hline & & \multicolumn{5}{c}{ including : } \\
\cline { 3 - 7 } District name & $\begin{array}{l}\text { Second crops } \\
\text { area, ha }\end{array}$ & Vegetables & Potato & Melon & $\begin{array}{l}\text { Maize } \\
\text { for grain }\end{array}$ & $\begin{array}{l}\text { Maize } \\
\text { for silage }\end{array}$ & Rice \\
\hline Bogdod & 3,579 & 627 & 188 & 116 & 975 & 1,373 & 300 \\
Buvayda & 3,516 & 584 & 171 & 76 & 858 & 1,277 & 550 \\
Dangara & 3,489 & 641 & 177 & 79 & 975 & 1,317 & 300 \\
Yozyovon & 3,917 & 673 & 181 & 182 & 936 & 1,345 & 600 \\
Quva & 3,840 & 1,099 & 286 & 24 & 967 & 1,444 & 20 \\
Oltiarik & 4,634 & 1,341 & 205 & 75 & 1,336 & 1,547 & 130 \\
Qushtepa & 3,565 & 729 & 147 & 52 & 981 & 1,356 & 300 \\
Rishton & 3,364 & 832 & 92 & 59 & 858 & 1,373 & 150 \\
Sokh & 379 & 104 & 242 & & & 33 & \\
Toshloq & 3,976 & 1,392 & 322 & 45 & 897 & 1,290 & 30 \\
Uzbekistan & 3,246 & 647 & 181 & 14 & 936 & 1,268 & 200 \\
Uchkuprik & 3,511 & 793 & 181 & 81 & 936 & 1,270 & 250 \\
Ferghana & 3,270 & 611 & 165 & 15 & 858 & 1,601 & 20 \\
Furkat & 3,086 & 587 & 194 & 119 & 858 & 1,228 & 100 \\
Total & 52,350 & 12,000 & 3,300 & 950 & 14,000 & 2,000 & 3,000 \\
\hline
\end{tabular}

\section{Results}

The ratio of second crops to winter wheat area for selected WUAs located in Andijan and Ferghana provinces are provided in Figures 5 and 6, respectively. These figures include the state limit for second-crop sowing (Dukhovny et al., 2012) and the volume of irrigation water received by the provinces (CAWater-Info, 2012) during the vegetation period (April-September). The state limit for second crops is set in the beginning of the vegetation season. Although officially all water limits are created at the beginning of each year from the forecast of available water, according to the key informant, the limits are set on the basis of water data from the previous year (interview with key informant, 05/06/2013). Officially, the water limits are corrected in June, but because the cropping season started already in April, farmers are unwilling to change their crops or reduce the irrigated area.

Within the observed period minimum water availability within the Andijan and Ferghana provinces was in 2009 and its maximum in 2006. However, for the Andijan Province the highest limit for double cropping was set in 2008. The reason for such differences between provinces is not clear. For the Ferghana Province the state limits to grow second crops are much more correlated with water availability, than for the Andijan Province. Overall, it can be observed that the water intake is much higher than the water limit, especially for the years when less water is expected. 


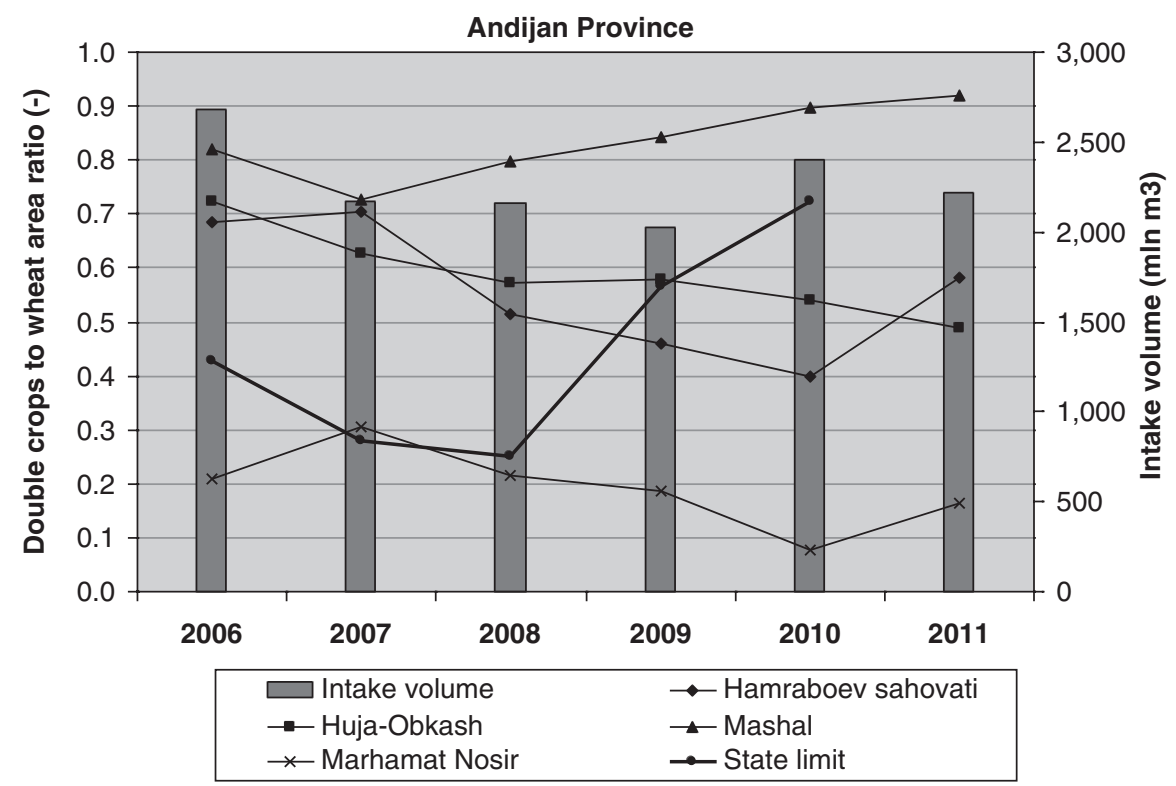

Figure 5. Ratio of second crops to wheat area for selected WUAs in the Andijan Province.

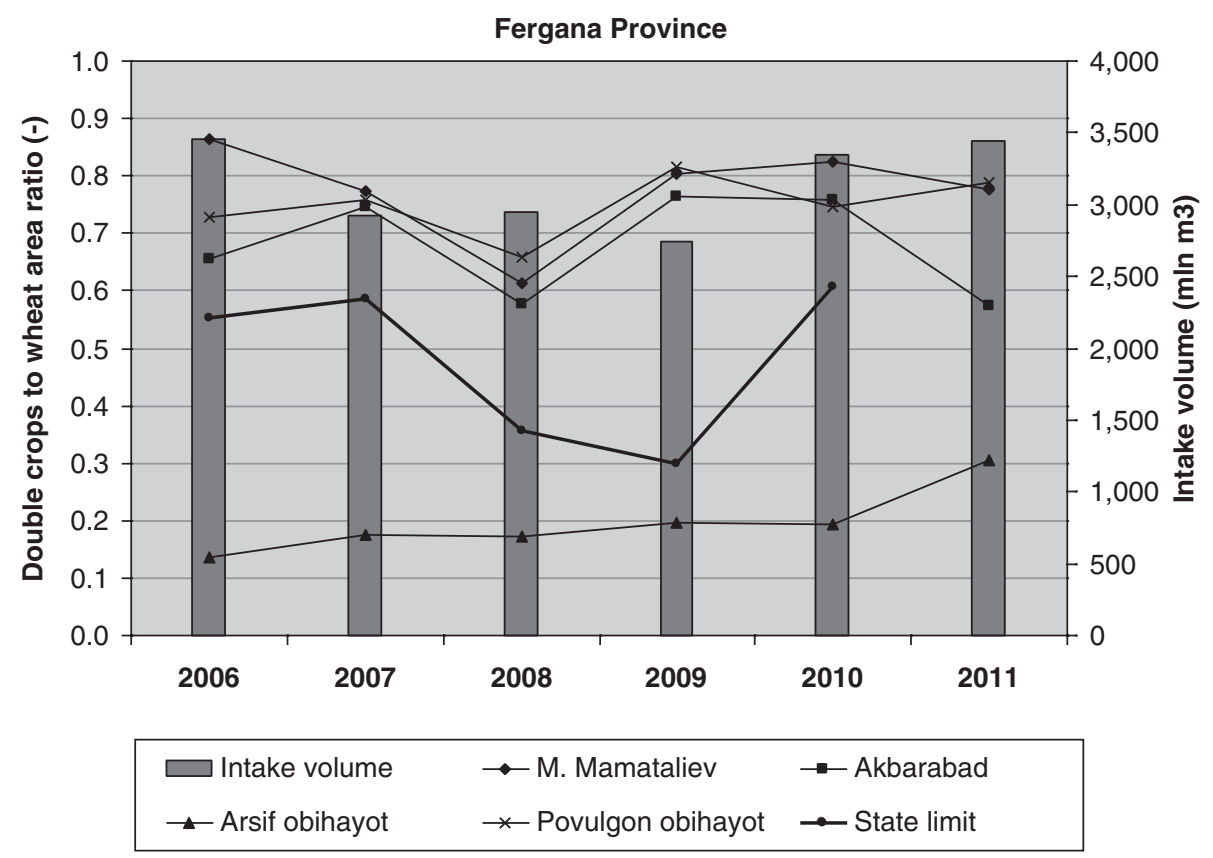

Figure 6. Ratio of second crops to wheat area for selected WUAs in the Ferghana Province.

Ratios of second crops to winter wheat area for all WUAs, located along the South Ferghana Canal (SFC) in the Andijan and Ferghana provinces are provided in Tables 5 and 6, respectively. There is no large difference in second crops to wheat area ratio linked to 
the WUAs location along SFC (the "head-tail" influence). The highest value of the ratio is in WUAs (Mashal and Dadahon Abror Asror) located in the middle of the SFC area. The lowest values are observed for WUAs (Marhamat Nosir and Arsif Obihayot), located rather far from the SFC, and large pumps are used to deliver water for irrigation of agricultural fields.

Having stated this, some WUAs, located higher than the SFC, benefit from additional water resources from transboundary tributaries, hence the irrigated area within the WUAs receives water from multiple sources (interview with key informant, 05/06/2013). Hence, some WUAs in Andijan province may have access to water from tributaries (Jalalkuduk vodiy imkoni WUA and Hoja obkash WUA from Akbura tributary and B. Rejapov from Aravan tributary). Besides, the WUAs Marhamat Nosir and T. Mirzaev receive additional water from Kyrgyzstan. Similarly, within the Ferghana province additional water sources from tributaries are utilized (Hojibek Zoirjonobod, Zarmirob Turgunboy and K. Umarov receive additional water from Isfairamsai and Oktepa Kirgizabad, Gishtmon obihayot and Yangiaryk obihayot from Margilonsai). However, there is no available data regarding the volume of water used from these other sources. Their access to additional water sources, other than lift irrigation would explain why some WUAs (like Kuva urtabuz anori, Yu. Ismonaliev, Arsif obihayot and Kalacha Salohiddinov) have relatively higher values compared to WUAs that only depend on lift irrigation (such as U. Karimov and Hojibek Zoirjonobod) ${ }^{7}$.

Overall, it appears that the determining factor for second crops is not water, but access to the water, either lift or gravity irrigation. In both provinces, it seems that having access to lift irrigation only is the reason for the limited area under second crops. However, given the resolution from the Ferghana Province it is not evident whether the district departments were responsible for limiting this area or whether this is the result of farmer decisions. Nevertheless, in either case, it appears that the plan for second crops is lower than the actual amount planted (interview with key informant, 05/06/2013).

Table 5

The ratio of second crops to winter wheat area for WUAs in the Andijan Province.

\begin{tabular}{|c|c|c|c|c|c|c|c|c|c|}
\hline \multirow[b]{2}{*}{ WUA Name } & \multirow{2}{*}{$\begin{array}{l}\text { Lift irrigation } \\
\text { area }(\%)\end{array}$} & \multicolumn{2}{|c|}{ Elevation $(\mathrm{m})$} & \multicolumn{6}{|c|}{ Ratio of second crops to winter wheat area $(-)$} \\
\hline & & Min & $\max$ & 2006 & 2007 & 2008 & 2009 & 2010 & 2011 \\
\hline $\begin{array}{l}\text { Sobirjonov } \\
\text { suv bulogi }\end{array}$ & 0 & 671 & 772 & 0.63 & 0.67 & 0.60 & 0.51 & 0.32 & 0.58 \\
\hline $\begin{array}{l}\text { Hamraboev } \\
\text { sahovati }\end{array}$ & 0 & 670 & 720 & 0.69 & 0.70 & 0.51 & 0.46 & 0.40 & 0.58 \\
\hline $\begin{array}{l}\text { Amir Temur } \\
\text { gidroservis }\end{array}$ & 0 & 632 & 706 & 0.74 & 0.69 & 0.66 & 0.70 & 0.59 & 0.70 \\
\hline $\begin{array}{l}\text { Jalalkuduk } \\
\text { vodiy } \\
\text { imkoni }\end{array}$ & 0 & 625 & 703 & 0.67 & 0.71 & 0.65 & 0.69 & 0.75 & 0.80 \\
\hline
\end{tabular}

(Continues)

${ }^{7}$ All of these WUAs make use of large pumping stations (7,000-10,000 KW, with lift from 50 to 200 meters). 
Table 5

(Continued)

\begin{tabular}{|c|c|c|c|c|c|c|c|c|c|}
\hline \multirow[b]{2}{*}{ WUA Name } & \multirow{2}{*}{$\begin{array}{l}\text { Lift irrigation } \\
\text { area }(\%)\end{array}$} & \multicolumn{2}{|c|}{ Elevation (m) } & \multicolumn{6}{|c|}{ Ratio of second crops to winter wheat area (-) } \\
\hline & & Min & $\max$ & 2006 & 2007 & 2008 & 2009 & 2010 & 2011 \\
\hline Huja obkash & 0 & 623 & 697 & 0.72 & 0.63 & 0.57 & 0.58 & 0.54 & 0.49 \\
\hline $\begin{array}{l}\text { Madiyarov } \\
\text { irrigatsiya }\end{array}$ & 90.3 & 677 & 703 & 0.30 & 0.50 & 0.31 & 0.38 & 0.21 & 0.38 \\
\hline Jura Palvan & 53.8 & 629 & 771 & 0.62 & 0.57 & 0.46 & 0.51 & 0.34 & 0.45 \\
\hline S.Kasimov & 14.1 & 572 & 752 & 0.66 & 0.66 & 0.63 & 0.69 & 0.66 & 0.61 \\
\hline B.Rajapov & 17.0 & 537 & 718 & 0.80 & 0.72 & 0.70 & 0.77 & 0.69 & 0.74 \\
\hline Tomchi Kuli & 7.5 & 540 & 650 & 0.79 & 0.54 & 0.54 & 0.58 & 0.64 & 0.88 \\
\hline Tojiboev & 23.6 & 551 & 608 & 0.78 & 0.77 & 0.63 & 0.68 & 0.62 & 0.81 \\
\hline $\begin{array}{l}\text { Marhamat } \\
\text { Nosir }\end{array}$ & 100 & 653 & 894 & 0.21 & 0.30 & 0.21 & 0.19 & 0.08 & 0.16 \\
\hline T.Mirzaev & 90 & 588 & 761 & 0.50 & 0.42 & 0.34 & 0.45 & 0.45 & 0.60 \\
\hline Pakhtakor & 10 & 539 & 645 & 0.90 & 0.68 & 0.76 & 0.73 & 0.76 & 0.94 \\
\hline Mashal & 5 & 556 & 710 & 0.82 & 0.73 & 0.80 & 0.84 & 0.90 & 0.92 \\
\hline
\end{tabular}

Table 6

The ratio of second crops to winter wheat area for WUAs in the Ferghana Province.

\begin{tabular}{|c|c|c|c|c|c|c|c|c|c|}
\hline \multirow[b]{2}{*}{ WUA Name } & \multirow{2}{*}{$\begin{array}{l}\text { Lift irrigation } \\
\text { area }(\%)\end{array}$} & \multicolumn{2}{|c|}{ Elevation (m) } & \multicolumn{6}{|c|}{ Ratio of second crops to winter wheat area (-) } \\
\hline & & $\min$ & $\max$ & 2006 & 2007 & 2008 & 2009 & 2010 & 2011 \\
\hline U.Karimov & 100 & 545 & 693 & 0.27 & 0.26 & 0.20 & 0.18 & 0.12 & 0.18 \\
\hline Buston bahor & 20 & 490 & 576 & 0.51 & 0.47 & 0.33 & 0.42 & 0.38 & 0.47 \\
\hline M. Mamataliev & 0 & 457 & 543 & 0.86 & 0.77 & 0.61 & 0.80 & 0.82 & 0.78 \\
\hline $\begin{array}{l}\text { Dadahon Abror } \\
\text { Asror }\end{array}$ & 0 & 482 & 541 & 0.92 & 0.86 & 0.86 & 0.92 & 0.91 & 0.92 \\
\hline $\begin{array}{l}\text { Kuva urtabuz } \\
\text { anori }\end{array}$ & 100 & 530 & 666 & 0.26 & 0.41 & 0.29 & 0.38 & 0.16 & 0.38 \\
\hline $\begin{array}{l}\text { Kodirjon } \\
\text { Azamjon }\end{array}$ & 0 & 449 & 538 & 0.62 & 0.63 & 0.63 & 0.77 & 0.81 & 0.73 \\
\hline Yu.Ismonaliev & 88.6 & 457 & 702 & 0.18 & 0.34 & 0.28 & 0.30 & 0.12 & 0.35 \\
\hline M.Ismoilov & 7.1 & 431 & 562 & 0.61 & 0.58 & 0.54 & 0.65 & 0.71 & 0.71 \\
\hline Akbarabad & 0 & 398 & 532 & 0.66 & 0.71 & 0.58 & 0.76 & 0.76 & 0.59 \\
\hline $\begin{array}{l}\text { Hojibek } \\
\text { Zoirjonobod }\end{array}$ & 100 & 512 & 597 & 0.21 & 0.24 & 0.17 & 0.19 & 0.16 & 0.19 \\
\hline $\begin{array}{l}\text { Kalacha } \\
\text { Salohiddinov }\end{array}$ & 100 & 549 & 618 & 0.09 & 0.21 & 0.15 & 0.25 & 0.32 & 0.26 \\
\hline Arsif obihayot & 100 & 520 & 639 & 0.14 & 0.18 & 0.17 & 0.20 & 0.20 & 0.31 \\
\hline $\begin{array}{l}\text { Yakkatut } \\
\text { obiravon }\end{array}$ & 0 & 434 & 532 & 0.69 & 0.74 & 0.55 & 0.65 & 0.68 & 0.71 \\
\hline
\end{tabular}


Table 6.

(Continued)

\begin{tabular}{|c|c|c|c|c|c|c|c|c|c|}
\hline \multirow[b]{2}{*}{ WUA Name } & \multirow{2}{*}{$\begin{array}{l}\text { Lift irrigation } \\
\text { area }(\%)\end{array}$} & \multicolumn{2}{|c|}{ Elevation (m) } & \multicolumn{6}{|c|}{ Ratio of second crops to winter wheat area $(-)$} \\
\hline & & $\min$ & $\max$ & 2006 & 2007 & 2008 & 2009 & 2010 & 2011 \\
\hline $\begin{array}{l}\text { Zarmirob } \\
\text { Turgunboy }\end{array}$ & 0 & 402 & 531 & 0.75 & 0.73 & 0.56 & 0.70 & 0.71 & 0.82 \\
\hline K.Umarov & 0 & 407 & 519 & 0.67 & 0.72 & 0.62 & 0.80 & 0.78 & 0.75 \\
\hline $\begin{array}{l}\text { Yangiarik } \\
\text { obihayot }\end{array}$ & 0 & 407 & 470 & 0.50 & 0.46 & 0.46 & 0.50 & 0.58 & 0.48 \\
\hline $\begin{array}{l}\text { Gishtmon } \\
\text { obihayot }\end{array}$ & 0 & 359 & 477 & 0.54 & 0.52 & 0.46 & 0.56 & 0.55 & 0.62 \\
\hline $\begin{array}{l}\text { Oktepa- } \\
\text { Kirgizobod }\end{array}$ & 0 & 347 & 509 & 0.68 & 0.67 & 0.70 & 0.78 & 0.70 & 0.71 \\
\hline $\begin{array}{l}\text { Fayzabod- } \\
\text { Shahimardan }\end{array}$ & 5 & 413 & 536 & 0.83 & 0.82 & 0.88 & 0.94 & 0.87 & 0.90 \\
\hline $\begin{array}{l}\text { Povulgon } \\
\text { obihayot }\end{array}$ & 5 & 371 & 527 & 0.73 & 0.76 & 0.66 & 0.82 & 0.75 & 0.79 \\
\hline
\end{tabular}

\section{Discussion and Conclusions}

The presented data show that ever since Uzbekistan introduced winter wheat and enabling state farms and farmers to grow a second crop the government has gone through different stages to control the production of the second crop. While in the beginning, growing second crops was even 'recommended', possibly after realizing that there is a competition of second crops with cotton production over the resource water, fertilizer and possibly labor, Uzbekistan appears to have discontinued the policy of second crops after the drought years of 2000. Nevertheless, it appears that individual provinces have introduced their own systems to deal with second crops. The examples from the two different provinces highlight that although Uzbekistan is perceived as a centralist state, provincial governments appear to have relative freedom with regard of handling the second crop after winter wheat. However, in the two described cases this relative freedom might work for the benefit of the individual provinces, but to the disadvantage of the national government, which benefits from cotton sales on the international market, as well as downstream provinces. Given that the reported area of second crops or the reported water utilization for provinces is understated, one could assume that the consequences of this freedom are not reported to the central government, and that the central government does not have the capacity to cross check provincial reporting. The example of second crops could therefore be a sign of losing central control over the provinces. From the province's perspective, the extent of the expansion of second crops could be interpreted as either a policy of toleration because the provinces are afraid to lose control over farmers who derive little benefit from growing state-order crops, or that provinces have already lost control over farmers. Hence, there appear two levels of anarchy, between state and provinces and between province and farmers. 
The shift in policies, as well as the current suggestion that farmers grow more second crops as mentioned within the provincial decree, highlights that the government authorities on the provincial level do not have the capacity to enforce strict regulations on second crops, which are the main cash earner for farmers. Approximating last year's area or water availability forecasts to make decisions on future second crop area appear to be inadequate and therefore would increase the competition between state-order crop and second crops for resources (labor, fertilizer and water). Compared to Conrad's (2006) and Veldwisch's (2007) previous findings on second crops the findings presented here clearly show that the limiting factor for second crops is based on the utilization of infrastructure for accessing the water resources. Hence, WUAs utilizing lift irrigation had significantly fewer areas under second crops than areas utilizing gravity irrigation.

Since the overall water availability within the basin for any given year are not easily determined in advance and in the case of the Syr Darya clearly depends on decision-making of an upstream state, any central planning regarding water resources and irrigated agriculture evidently has its limitations. The additional competition between non-commercial stateorder crops and commercial crops exacerbates the pressure for planning. It appears that the GoU has still not found the right balance and has so far clearly underestimated market forces. To alleviate the uncertainty about water available, it is evident that the GoU has to come to an agreement with the upstream riparian states on water resources. In addition, given that there is underreporting of water utilization as well as grown crops the control mechanisms within the provinces have to be reinforced as well as a unit cross-checking the data submitted by the provinces, which can hold the provinces accountable for potential damage to downstream provinces (not even considering the interest of downstream riparian states or the environment at large). Given that there is such competition between commercial and state-order crops it appears necessary for the GoU to revisit the state-order crop policy and to make it more attractive to farmers so that the competition between crops and other resources is eased.

\section{Acknowledgements}

We would like to thank the CGIAR Research Program on Water, Land and Ecosystems as well as Dryland Systems for their financial support. The study design, data collection, analysis and interpretation of the result were undertaken exclusively by the authors.

\section{References}

Abdullaev, I., de Fraiture, C., Giordano, M., Yakubov, M., \& Rasulov, A. (2009). Agricultural water use and trade in Uzbekistan: Situation and potential impacts of market liberalization. International Journal of Water Resources Development, 25(1), 47-63.

Barker, R., \& Molle, F. (2004). Evolution of irrigation in South and Southeast Asia (Comprehensive Assessment Research Report 5). Colombo, Sri Lanka: Comprehensive Assessment Secretariat.

Benjaminovich, Z. M., \& Tersitskiy, D. K. (1975). Irrigation of Uzbekistan II [in Russian]. Tashkent, Uzbekistan: Fan. 
Bolding, A. (2004). In hot water: A study on social technical intervention models and practices of water use in smallholder agriculture, Nyanyadzi catchment, Zimbabwe (Doctoral dissertation). Wageningen University, Wageningen, The Netherlands.

Bressers, H., \& Kuks S. (2013). Water governance regimes: Dimensions and dynamics. International Journal of Water Governance, 1, 133-156.

CAWater-Info. (2012). Retrieved from http://www.cawater-info.net/

Conrad, C. (2006). Fernerkundungsbasierte Modellierung und hydrologische Messungen zur Analyse und Bewertung der landwirtschaftlichen Wassernutzung in der region Khorezm (Uzbekistan). Würzburg, Germany: Bayerischen Julius-Maximilians-Universität Würzburg.

Decree \#129 from the 23/06/2011 of the Ferghana Province Hokim on Allocation of Secondary Crops in Areas Freed from the Grain crops. Ferghana city, Ferghana Province.

Djanibekov, N., Rudenko, I., Lamers, J. P. A., \& Bobojonov, I. (2010). Pros and cons of cotton production in Uzbekistan, case study of the program: "Food policy for development countries: the role of government in the global food system." Retrieved from http://chatt.hdsb.ca/ blairj/course_files/FOV1-001625C2/cotton\% 20case\%20study.pdf

Dukhovny, V. (2002). Big challenges and limited opportunities: What are the constraints on cooperation. In J. Bogardi \& S. Castelein (Eds.), From conflict to co-operation in international water resources management: challenges and opportunities (pp. 119-124). Delft, The Netherlands: UNESCO-IHE.

Dukhovny, V. A., Sokolov, V. I., Galustyan, A., Djalalov, A. A., Mirzaev, N. N., Horst, M. G., . . Miyzamidinov, N. (2012). Scientific Information Center (SIC) Report on Comprehensive Hydrographic Study of the Fergana Valley: Integrated Water Resources Management in Ferghana Valley Project (IWRM-Ferghana) Phase V. Tashkent: SIC.

Ertsen, M. (2006). Colonial irrigation: Myths of emptiness. Landscape Research, 31(2), 147-167.

Government of Uzbekistan. (1993). Decree of cabinet ministries of Uzbekistan on measures to increase gross harvesting of grain cereal crops on irrigated lands. Retrieved from http://www.lex.uz/Pages/GetAct .aspx?lact_id $=631724 \&$ type $=$ doc

Government of Uzbekistan. (1998). Decree of cabinet of ministries of Uzbekistan on measures to improve production of mixed-feed for livestock, poultry and fisheries for the period of 1998-2000. Retrieved from http://www.lex.uz/Pages/GetAct.aspx?lact_id=1604421\&type=doc

Ingram, H. (2008). Beyond universal remedies for good water governance: A political and contextual approach. Retrieved from http://rosenberg.ucanr.org/documents/V\%20Ingram.pdf

Jones, L. P. (2000). Sources of institutional continuity: The soviet legacy in Central Asia. Retrieved from http:// www.yale.edu/macmillan/ocvprogram/licep/2/luong/luong.pdf

Lustick, I. S. (2002). Hegemony and riddle of nationalism: The dialectics of nationalism and religion in the Middle East. Logos: A journal of modern society and culture, 1(3), 18-44.

Markham, B. L., \& Barker, J. L. (1987). Radiometric properties of U.S. processed Landsat MSS data. Remote Sensing of Environment, 22, 39-71.

Massicard, E., \& Trevisani, T. (2003). The Uzbek mahalla: Between state and society. In T. Everett-Heath (Ed.), Central Asia: Aspects of transition (pp. 205-218). London, England: Routledge Curzon.

Meinzen-Dick, R. (2007). Beyond panaceas in water institutions. Proceedings of the National Academy of Sciences of the United States of America, 104(39), 15200-15205.

Mollinga, P. (2003). On the waterfront. New Delhi, India: Orient Longman.

Mukherji, A., \& Shah, T. (2005). Groundwater socio-ecology and governance: A review of institutions and policies in selected countries. Hydrogeology Journal, 13, 328-345.

Mukhamedova, N., \& Wegerich, K. (2014). Integration of villages into WUAs - The rising challenge for local water management in Uzbekistan, International Journal of Water Governance, 2. doi:10.7564/13-IJWG19

Neckel, H., \& Labs, D. (1984). The solar radiation between 3300 and 12500 A. Solar Physics, 90, 205-258.

Plusquellec, H. (2002). How design, management and policy affect the performance of irrigation projects: Emerging modernization procedures and design standards. Bangkok, Thailand: FAO. Retrieved from ftp:// ftp.fao.org/docrep/fao/004/ac799e 
Pomfret, R. (2000). Agrarian reform in Uzbekistan: Why has the Chinese model failed to deliver? Economic Development and Cultural Change, 48, 269-282.

Rahaman, M. M., \& Varis, O. (2005). Integrated water resources management: Evolution, prospects and future challenges. Sustainability: Science, Practice, \& Policy, 1(1), 15-21.

Rasanayagam, J. (2003). Market, state and community in Uzbekistan: Reworking the concept of the informal economy (Max Planck Institute for Social Anthropology, Working Paper No. 59). Retrieved from http:// www.eth.mpg.de/cms/en/publications/working_papers/wp0059.html

Seckler, D. (1982). The emerging crisis of irrigation management in the LDCs, Mimeo. (Ford Foundation, New Delhi).

Shah, T. (2009). Taming the anarchy: Groundwater governance in South Asia. Washington: Resources of the Future.

Spoor, M. (1998). The Aral Sea basin crisis: Transition and environment in former Soviet Central Asia. Development and Change, 29(3), 409-435.

Spoor, M., \& Krutov, A. (2003). The "power of water" in a divided Central Asia. Perspectives on Global Development and Technology, 2(3-4), 593-614.

Teisman, G., van Buuren, A., Edelenbos, J., \& Warner, J. (2013). Water governance: Facing the limits of managerialism, determinism, water centricity and technocratic problem solving. International Journal of Water Governance, 1, 1-11.

Trevisani, T. (2007). After the Kolkhoz: Rural elites in competition, Central Asian Survey, 26(1), 85-104.

Uphoff, N. T. (1986). Improving international irrigation management with farmer participation: Getting the process right. Boulder, CO: Westview Press.

Uphoff, N. T. (1991). Managing irrigation: Analyzing and improving the performance of bureaucracies. Newbury Park, London: Sage.

Veldwisch, G. J. A. (2007). Cotton, rice and water: The transformation of agrarian relations, irrigation technology and water distribution in Khorezm, Uzbekistan (Doctoral dissertation). Rheinischen FriedrichWilhelms-Universität Bonn, Würzburg, Germany.

Veldwisch, G. J. A., \& Spoor, M. (2008). Contesting rural resources: Emerging ‘forms' of agrarian production in Uzbekistan. Journal of Peasant Studies, 35(3), 424-451.

Wade, R. (1984). Irrigation reform in condition of populist anarchy: An Indian case. Journal of Development Economics, 14, 285-303.

Warner, J., Wester, P., \& Bolding, A. (2008). Going with the flow: River basins as the natural units for water management? Water Policy, 10(Suppl. 2), 121-138.

Water Governance Facility. (2014). What is water governance? UNDP Water Governance Facility at SIWI, Stockholm, Sweden. Retrieved March 2014 from: http://www.watergovernance.org/sa/node.asp?node=846

Wegerich, K. (2004a). Coping with disintegration of a river-basin management system: Multi-dimensional issues in Central Asia. Water Policy, 6(4), 335-344.

Wegerich, K. (2004b). Informal network utilisation and water distribution in two districts in the Khorezm Province, Uzbekistan. Local Environment, 9(4), 337-352.

Wegerich, K. (2004c). Organizational problems of water distribution in Khorezm, Uzbekistan. Water International, 29(2), 130-137.

Wegerich, K. (2005). What happens in a merger? Experiences of the state department for water resources in Khorezm, Uzbekistan. Physics and Chemistry of the Earth, 30(6-7), 455-462.

Wegerich, K. (2006). "A little help from my friend?" Analysis of network links on the meso level in Uzbekistan. Central Asian Survey, 25(1-2), 115-128.

Wegerich, K. (2007). A critical review of the concept of equity to support water allocation at various scales in the Amu Darya basin, Irrigation and Drainage Systems, 21(3-4), 185-195.

Wegerich, K. (2010). Handing over the sunset - External factors influencing the establishment of water user associations in Uzbekistan: Evidence from Khorezm Province. Göttingen, Germany: Cuvillier Verlag.

Wegerich, K. (2011). Water resources in Central Asia: Regional stability or patchy make-up? Central Asian Survey, 30(2), 275-290. 
Wegerich, K., Kazbekov, J., Mukhamedova, N., \& Musayev, S. (2012). Is it possible to shift to hydrological boundaries? The Ferghana Valley Meshed System. International Journal of Water Resources Development, $28(3), 545-564$.

Weinthal, E. (2001). Sins of omission: Constructing negotiating sets in the Aral Sea Basin. Journal of Environment and Development, 10(1), 50-79.

Wittfogel, K. A. (1957). Oriental despotism: A comparative study of total power. New York, NY: Vintage Books.

Yakubov, M. (2013). The 2011 impact assessment study: Project impacts on the population at Large (kitchen gardeners' perspective) (IWRM Ferghana Valley Project). Battaramulla, Sri Lanka: IWMI-Central Asia. 
